\begin{tabular}{|c|c|}
\hline 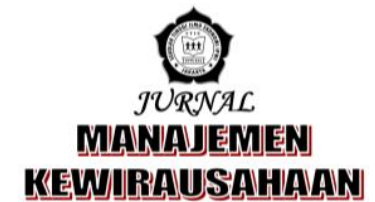 & $\begin{array}{r}\text { p-ISSN 1858-1048 } \\
\text { e-ISSN 2654-9247 } \\
\text { http://ejurnal.stieipwija.ac.id/index.php/imk } \\
\text { DOI: http://dx.doi.org/10.33370/imk.v16i1.315 } \\
\text { Jurnal Manajemen Kewirausahaan Vol. 16 No. 01 - Juni } 2019 \\
\text { Submit: 14 Mei 2019; Review: 25 Jun 2019; Publish: } 30 \text { Jun } 2019\end{array}$ \\
\hline
\end{tabular}

\title{
NILAI KEPUASAN PELANGGAN: KESESUAIAN HARGA DAN KUALITAS PELAYANAN YANG DIRASAKAN KONSUMEN
}

\author{
Oleh: \\ Surya Bintarti \\ surya.bintarti@pelitabangsa.co.id \\ Sekolah Tinggi Ilmu Ekonomi Pelita Bangsa
}

\begin{abstract}
ABSTRAK
Kecenderungan peningkatan jumlah pengguna jasa kereta api adalah suatu perkembangan yang yang sangat pesat, namun sebagaimana diketahui bahwa kualitas yang ditawarkan oleh jasa kereta api juga semakin baik, sehingga tingginya peningkatan pengguna jasa kereta api ini juga diimbangi oleh adanya perkembangan kualitas yang diberikan dengan dibarengi pula oleh adanya kenaikan harga yang diterapkan, namun demikian hal ini juga dibarengi oleh adanya peningkatan pelayanan yang diberikan dengan diiringi oleh adanya kenaikan harga yang ditetapkan, adalah salah satu kebijakan yang diambiloleh perusahaan perkeretaapian Indonesia untuk meningkatkan kepuasan konsumen sebagai pengguna jasa ini. Penetapan kesesuaian harga yang ditetapkan dari pihak kereta api dan kualitas pelayanan yang diberikan berpengaruh terhadap kepuasan pelanggan pengguna jasa kereta commuter linesebesar 30,6\%, sehingga dapat dikatakan bahwa harga dan kualitas pelayanan memberikan pengaruh yang positif, walupun relative rendah,hal ini dikarenakan adanya ketidaksesuaian antara harga yang ditetapkan atau dicantumkan dengan kesesuaian dalam realisasi harga, dan sisanya sebesar 60,6\% dipengaruhi oleh variabel bebas lain.
\end{abstract}

Kata Kunci: harga, kualitas pelayanan, kepuasan pelanggan

\section{PENDAHULUAN}

Perkembangan perkeretaapian Indonesia dari sejak tahun sembilan puluhan hingga saat ini, sangat luar biasa menunjukkan kemajuan yang baik, sehingga menciptakan rasa kepuasan yang dirasakan konsumen sebagai penggunanya, walaupun perkembangan tersebut diikuti oleh kenaikan harga tiket, namun kenaikan tersebut juga diimbangi oleh meningkatkan sarana dan prasarana yang ditawarkan oleh perusahaan perkeretaapian Indonesia sebagai bentuk pelayanan yang ditawarkan, dengan harapan agar masyarakat sebagai pengguna jasa kereta api, dimana dalam hal ini mereka adalah konsumen, yang diharapkan akan merasa puas setelah menggunakan jasa kereta api. Nilai kepuasan yang dirasakan oleh konsumen akan dapat dipengaruhi oleh beberapa faktor atau variable, dan semua yang dirasakan oleh konsumen tersebut adalah merupakan suatu proses yang kemudian berbentuk kualitas pengalaman yang dirasakan konsumen (Bintarti, 2017). Faktor atau variable penting variabel harga, karena 
variable atau faktor kesesuaian harga ini adalah sangat berpengaruh secara signifikan terhadap kepuasan konsumen. Faktor atau variable lain yang tak kalah penting daripada kesesuaian harga terhadap rasa kepuasan yang dirasakan konsumen, adalah kualitas pelayanan yang diberikan ketika konsumen menikmati produk yang dibeli oleh konsumen.

Kualitas pelayanan dengan kepuasan yang dirasakan oleh konsumen sebagai pengguna produk yang ditawarkan adalah suatu capaian yang diharapkan oleh produsen sebagai pihak yang menawarkan, untuk itu tidak sedikit bahkan hamper semua perusahaan yang bertindak sebagai produsen merekrut staf yang memiliki kompetensi sesuai dengan yang dibutuhkan, hal ini sangat penting karena kompetensi sumber daya yang dimiliki merupakan aspek penting bagi pelanggan dalam menilai kualitas layanan yang akan dinikmati oleh konsumen. Kepuasan pelanggan sangat bergantung pada memastikan bahwa perusahaan mempertahankan standar kualitas layanan yang baik kepada para konsumennya, hal ini menunjukkan bahwamekanisme kualitas penempatan berpengaruh signifikan terhadap tingkat kepuasan pelanggan. Pimpinan perusahaan dalam hal ini para manajer, mengimplimentasikan bahwa memberikan nilai rasa kepuasan kepada konsumen adalah dengan memeberikan layanan yang maksimal, dan hal merupakan strategi membangun merek bagi produk yang dihasilkannya.Indikasi strategi membangun merek yang sukses dapat diterjemahkan ketika dapat ditemukan pada saat perusahaan memberikan layanan yang berkualitas terhadap konsumennya, sehingga konsumen merasa sangat puas (Agyapong, 2011).

Keberlangsungan produk akan sangat tergantung kepada rasa kepuasan yang dirasakan oleh konsumen, dimana kepuasan konsumen ini dipengaruhi oleh adanya kesesuaian harga dan kualitas pelayanan yang dirasakan oleh sang konsumen (Olifia dan Agustin, 2016).
Kesesuaian harga dan kualitas pelayanan yang ditawarkan secara parsial memiliki peranan yang signifikan dan positif terhadap kepuasan pelanggan pengguna jasa transportasi taksi Blue Bird di Surabaya, hal ini mengindikasikan bahwa kesesuaian harga yang diterapkan dan semakin baik kualitas pelayanan maka kepuasan pelanggan semakin meningkat (Zakaria, 2017), dan hal uang menarik lagi adalah bahwa kesesuain harga dan kualitas pelayanan berperan signifikan secara simultan terhadap kepuasan konsumen(Wijaya, 2017).

\section{TUJUAN PENELITIAN}

Tujuan penelitian adalah untuk melihat Nilai kepuasan pelanggan berdasarkan kesesuaian harga dan kualitas pelayanan yang dirasakan konsumen

\section{TELAAH LITERATUR DAN PENGEMBANGAN HIPOTESIS Kepuasan Pelanggan}

Terdapat empat metode untuk mengukur kepuasan pelanggan: sistem keluhan dan saran, ghost shopping, lost costumer analysis, dan survey kepuasan pelanggan.

- Sistem Keluhan dan Saran, setiap organisasi yang berorientasi pada pelanggan (customer oriented) perlu memberikan kesempatan dan akses yang mudah serta nyaman bagi para pelanggannya guna menyampaikan saran, pendapat, dan keluhan mereka. Media yang digunakan bisa berupa kotak saran, kartu komentar dikirim melalui via pos, saluran telepon khusus bebas pulsa, website, dan lain-lain.

- Ghost Shopping (Mystery Shopping), satu cara memperoleh gambaran mengenai kepuasan pelanggan adalah dengan mempekerjakan beberapa orang (ghost shoppers) untuk berperan atau berpura-pura sebagai pelanggan potensial produk perusahaan dan pesaing. Mereka diminta berinteraksi dengan staff penyedia jasa dan menggunakan 
produk atau jasa perusahaan, kemudian melaporkan temuantemuannya berkenaan dengan kekuatan dan kelemahan produk perusahaan dan pesaing.

- Lost Customer Analysis, sedapat mungkin perusahaan seyogyanya menghubungi para pelanggan yang telah berhenti membeli atau yang telah pindah pemasok agar dapat memahami mengapa hal itu terjadi dan supaya dapat mengambil kebijakan perbaikan atau penyempurnaan selanjutnya.

- Survei Kepuasan Pelanggan, umumnya banyak penelitian mengenai kepuasan pelanggan yang dilakukan dengan penelitian survei, baik melalui survei pos, telepon, email, websites, maupun wawancara langsung.

\section{Harga}

Harga merupakan nilai tertentu yang harus dibayar atas nilai suatu produk atau jasa yang telah dibeli atau digunakan. Harga menjadi nilai agregat dari semua hal yang diberikan produsen terhadap pelanggan dalam mendapatkan keuntungan memiliki atau menggunakan suatu produk atau jasa.

Harga merupakan suatu nilai yang dibuat untuk menjadi patokan nilai suatu barang atau jasa.Harga juga dapat mempengaruhi kepuasan pelanggan. Dimana harga berperan penting dalam menentukan keputusan pelanggan untuk membeli barang atau jasa. Sejumlah uang yang dibebankan atas suatu barang atau jasa atau jumlah dari nilai uang yang ditukar konsumen atas manfaat-manfaat karena memiliki atau menggunakan produk atau jasa tersebut (Kotler dan Armstrong, 2012).

Tingkat harga terjadi dipengaruhi oleh beberapa faktor, seperti keadaan perekonomian, permintaan dan penawaran, elastisitas permintaan, persaingan, biaya, tujuan perusahaan, dan pengawasan pemerintah.

H1: dinyatakan bahwa harga tiket yang ditetapkan kereta commuter line akan memberikan kepuasan terhadap pengguna jasa kereta api.

\section{Kualitas Pelayanan}

Kualitas pelayanan dapat dipahami sebagai suatu upaya pemenuhan kebutuhan dan keinginan konsumen, serta ketepatan penyampaian untuk mengimbangi harapan konsumen (Tjiptono, 2010:259). Pelayanan secara spesifik harus memperlihatkan kebutuhan dan keinginan konsumen karena jasa yang disarankan langsung oleh konsumen akan segera mendapat penilaian sesuai atau tidak sesuai dengan harapan dan penilaian konsumen.

Kualitas pelayanan berfokus pada upaya pemenuhan kebutuhan dan keinginan konsumen serta ketepatan penyampaiannya untuk mengimbangi harapan konsumen.

Ada lima dimensi pokok yang dapat digunakan untuk mengukur kualitas pelayanan, yaitu (Parasuraman, Zeithaml, dan Berry dalam buku Fandy Tjiptono, 2012) 1) Bukti Langsung (Tangibles), 2) Keadaan (Reliability), 3) Daya Tanggap (Responsiveness), 4) Jaminan (Assurance), 6) Empati (Empathy).

H2: dinyatakan bahwa kualitas pelayanan yang diberikan oleh pihak kereta commuter line akan berdampak pada kepuasan pengguna jasa kereta api.

\section{Hubungan Kepuasan Konsumen dengan Kualitas Layanan dan Harga}

Berlangsungnya suatu kegiatan bisnis atau usaha akan sangat dipengaruhi oleh rasa kepuasan yang dirasakan oleh konsumen, dimana hal ini akan berdampak kepada loyalitas konsumen sehingga kemungkinan konsumen untuk kembali membeli produk tersebut kemungkinan besar akan terjadi, bahkan konsumen dengan senang hati akan merekomendasikannya kepada orang lain. Hal ini menunjukkan bawasanya bahwa kualitas layanan sangat berhubungan positif dengan loyalitas konsumen sebagai pelanggannya, bahkan konsumen tidak akan resah dan khawatir ketika ditarik biaya harga mahal, sehingga kecenderungan untuk membayar lebih bukan masalah bagi seorang konsumen (Bolton and Myers, 2003). 
Kualitas layanan dipandang sebagai penentu jangka panjang suatu perusahaan sukses. Kualitas layanan sebagai pelanggan merupakan proses evaluasi standar layanan yang diterima di seluruh konsumen dan merupakan variable yang paling dominan dalam mengukur keandalan, daya tanggap, dan empati konsumen, untuk itu kita perlu melihat persepsi kualitas layanan secara keseluruhan sebagai variable penilaian ketergantungan dan keakuratan layanan yang dirasakan oleh konsumen, hal ini adalah bentuk kinerja (keandalan), kemauan penyedia untuk membantu pelanggan dan menyediakan layanan yang cepat (responsif), dan penyediaan perhatian, perhatian individual (empati /peduli) (Parasuraman et al., 1988). Mengukur persepsi atas kualitas layanan, daripada harapan dan persepsi, merupakan alat ukur untuk mengukur kepuasan konsumen Cronin dan Taylor (1992).

Komitmen memberikan rasa kepuasan kepada konsumen adalah orientasi jangka panjang bagi pelanggan dan hal adalah merupakan hubungan positif dalam kegiatan bisnis dengan para pelanggannya (Moorman et al., 1992; Morgan dan Hunt, 1994).

Usaha perusahaan untuk bisa memberikan rasa kepuasan kepada konsumen, adalah suatu orientasi yang didasarkan pada ikatan emosional pelanggan sebagai konsumen dengan produk yang dikonsumsinya (Moorman et al., 1992; Morgan dan Hunt, 1994; Geyskens et al., 1996).

Perasaan kepuasan yang dirasakan pelanggan sebagai konsumen merupakan kesesuaian antara harapan dan manfaat yang diiinginkan dengan implimentasi yang benar-benar dirasakan (Geyskens et al., 1996).

Komitmen pengusaha sebagai produsen akan benar-benar memberikan rasa kepuasan kepada konsumen sebagai pelanggan akan membentuk kedekatan hubungannya dengan produk tersebut sehingga akan membentuk rasa loyalitas kepada pelanggan sebagai konsumennya (Geyskens et al.,1999), dan seiringnya dengan waktu maka loyalitas tersebut akan semakin meningkat (Morgan dan Hunt, 1994).

Diferensiasi layanan adalah penting untuk hubungan bisnis yang sukses, dengan tanpa mempertimbangkan potensi berbasis biaya biasanya pelanggan sebagai konsumen akan tetap menjalin hubungan bisnis-ke-bisnis.

Fokus pada peran diferensiasi layanan dan penerapan harga dalam menghasilkan hal yang penting, yaitu kepuasan pelanggan sebagai konsumen maka dijamin bahwa loyalitas pasti akan tercapai (Cannon dan Homburg, 2001).

Berdasarkan pada kajian teori tersebut diatas maka dapat ditarik di dalam kerangka penelitian sebagai berikut.

Gambar 1

Kerangka/Konstelasi

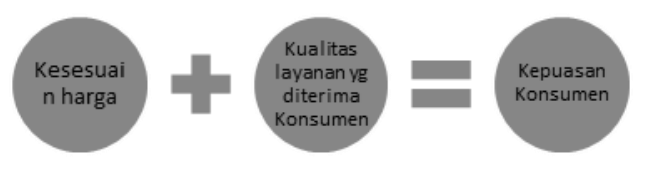

\section{METODE PENELITIAN}

Penelitian ini menggunakan metode kuantitatif, dengan diperkuat dengan penelitian kualitatif, dimana populasi dalam penelitian ini adalah konsumen yang pernah menggunakan jasa kereta commuter line jabodetabek di Stasiun Cikarang.

\section{Sampel Penelitian}

Teknik pengambilan sampel penelitian ini dengan metode nonprobability sampling yaitu teknik pengambilan sampel yang tidak memberi peluang atau kesempatan sama bagi setiap unsur atau anggota populasi untuk dipilih menjadi sampel. Metode nonprobability sampling yang digunakan adalah teknik purposive sampling dengan jumlah sampel 100 responden. Hal ini dikarenakan jumlah populasinya sangat besar dan tidak terbatas (infinit).

Berdasarkan responden tersebut maka dikumpulkan data-data yang dibutuhkan, dimana teknik 
pengumpulan dilakukan dengan observasi, kuesioner dan studi pustaka, dan setelah data terkumpul maka dilakukan uji validitas dan reabilitas dan kemudian ditindak lanjuti dengan uji pengolahan data penelitian.

\section{HASIL DAN PEMBAHASAN Hasil Penelitian Analisa Deskriptif}

Kereta commuter line sebagai salah satu alat transportasi darat yang murah, hemat lahan, hemat energi dan rendah polusi karena bersifat masal sehingga diharapkan bisa memenuhi kebutuhan transportasi masyarakat.Transportasi commuter line merupakan suatu perkembangan teknologi yang dapat memudahkan dalam melakukan aktifitas, dengan kemudahan transportasi tersebut cenderung akan meningkatkan keinginan seseorang untuk melakukan mobilitas dari satu tempat ke tempat yang lain. Hal ini sejalan dengan apa yang dikemukakan oleh Ravenstein yang diulas Adioetomo dan Samosir (2010)bahwa perkembangan teknologi akan memberikan efek terhadap kecenderungan untuk meningkatkan angka mobilitas baik permanen maupun non permanen.

Per 31 Desember 2016 dalam websitenya (www.kr.co.id) menjelaskan KCJ mengelola rute operasi KRL Commuter Line sebagai berikut:

Tabel 1

Jumlah Penumpang Kereta Commuter Line Tahun 2011-2016

\begin{tabular}{|c|c|c|}
\hline No & Tahun & $\begin{array}{c}\text { Jumlah Penumpang } \\
\text { Wilayah Jabodetabek } \\
\text { (Juta Orang) }\end{array}$ \\
\hline 1 & 2011 & 121.1 \\
\hline 2 & 2012 & 134.1 \\
\hline 3 & 2013 & 158.5 \\
\hline 4 & 2014 & 208.5 \\
\hline 5 & 2015 & 257.5 \\
\hline 6 & 2016 & 280.6 \\
\hline
\end{tabular}

Sumber: Badan Pusat Statistik PT. Kereta Commuter Line

Data tersebut dapat diketahui bahwa penumpang menggunakan kereta commuter line mengalami kenaikan setiap tahun nya (laporan tahunan 2011 - 2016). Hal itu menunjukkan bahwa kereta commuter line masih diminati. Sehingga perusahaan dituntut untuk meningkatkan kinerja dengan memberikan pelayanan, kenyamanan, dan keamanan ekstra kepada para pelanggannya.

Direktur PT. KAI Ignasius Jonan menyatakan bahwa adapun beberapa alasan yang mempengaruhi konsumen memilih jasa transportasi kereta api hal itu dapat dilihat pada tabel berikut.

Tabel 2

Alasan Memilih Menggunakan

Tranportasi Kereta Commuter Line

\begin{tabular}{|c|l|c|c|}
\hline No & $\begin{array}{l}\text { Alasan } \\
\text { Kereta Memilih } \\
\text { Line }\end{array}$ & $\begin{array}{c}\text { Jumla } \\
\mathrm{h}\end{array}$ & $\begin{array}{c}\text { Persent } \\
\text { ase }\end{array}$ \\
\hline 1 & Harga lebih murah & 110 & $28 \%$ \\
\hline 2 & $\begin{array}{l}\text { Sudah terbiasa } \\
47\end{array}$ & $12 \%$ \\
\hline 3 & Merasa lebih aman & 42 & $11 \%$ \\
\hline 4 & Merasa nyaman & 99 & $25 \%$ \\
\hline 5 & $\begin{array}{l}\text { Dapat menampung } \\
\text { banyak orang }\end{array}$ & 6 & $2 \%$ \\
\hline 6 & $\begin{array}{l}\text { Dekat stasiun } \\
\text { praktis ) }\end{array}$ & 19 & $5 \%$ \\
\hline 7 & $\begin{array}{l}\text { Cepat menghindari } \\
\text { kemacetan }\end{array}$ & 70 & 185 \\
\hline 8 & $\begin{array}{l}\text { Lainnya } \\
\text { Total }\end{array}$ & 400 & $100 \%$ \\
\hline
\end{tabular}

Dari tabel di atas, dapat diketahui bahwa harga yang lebih murah merupakan alasan utama dengan persentase tertinggi, pada urutan kedua perasaan lebih nyaman dengan menggunakan jasa transportasi kereta api, selain itu kereta yang dianggap lebih cepat dan terhindar dari kemacetan berada pada posisi ketiga. Hal ini berarti bahwa harga merupakan sejumlah uang yang akan dikeluarkan oleh konsumen untuk mendapat barang atau jasa yang dinginkan. Konsumen akan sangat sensitif mengenai harga karena konsumen akan membandingkan harga dengan apa yang didapat. Sedangkan tarif KRL lebih murah daripada angkutan darat yang lain, terutama sejak diberlakukannya tarif progresif bersubsidi pada 1 Juli 2013. 
Tabel 3

Tarif yang Dibebankan Penumpang

\begin{tabular}{|c|c|c|c|}
\hline No & $\begin{array}{c}\text { Jenis } \\
\text { Angkutan } \\
\text { KA }\end{array}$ & Lintasan & $\begin{array}{c}\text { Tarif/Orang } \\
\text { (Rp) }\end{array}$ \\
\hline 1 & KRL & $\begin{array}{c}1-25 \mathrm{KM} \\
\text { Pertama }\end{array}$ & 3.000 \\
\hline 2 & KRL & $\begin{array}{c}10 \mathrm{KM} \\
\text { Berikutnya } \\
\text { dan berlaku } \\
\text { kelipatan }\end{array}$ & 1.000 \\
\hline
\end{tabular}

Sumber: KAI

Berdasarkan tabel tersebut, konsumen lebih menyukai kualitas layanan ketika harga dan elemen biaya lainnya tetap konstan (Turban, 2002 dalamGloria K.Q. Agyapong, 2011). Oleh karena itu, mempertahankan pelanggan adalah lebih penting daripada menarik konsumen baru. Banyak faktor yang dapat mempengaruhi kepuasan dan loyalitas konsumen dalam menggunakan jasa transportasi, diantaranya adalah kualitas pelayanan dan penentuan kebijakan harga.

Responden dalam penelitian ini adalah konsumen yang pernah menggunakan jasa kereta commuter line jabodetabek di Stasiun Cikarang dengan jumlah 100 orang. Maka dapat diketahui gambaran umum responden berdasarkan usia, jenis kelamin, pendidikan terakhir, pekerjaan dan frekuensi menggunakan kereta commuter line yang peneliti miliki dari hasil penelitian bahwa responden terdiri dari bahwa responden berjenis kelamin laki - laki sebanyak 44 (44\%) orang, dan berjenis kelamin perempuan sebanyak $56(56 \%)$ orang. Berdasarkan usia responden memiliki usia rata - rata yaitu 26 - 35 tahun. Berdasarkan latar belakang pendidikan memiliki tingkat pendidikan terakhir SMA sederajat. Berdasarkan pekerjaan menunjukan respoden berdasarkan profesi sebagai PNS sebanyak 14 (14\%) orang, dan profesi sebagai pegawai swasta sebanyak $86(86 \%)$ orang. Berdasarkan hasil penelitian bahwa responden yang pernah menggunakan kereta commuter line dengan frekuensi penggunaan $1-3 \mathrm{x}$ sebanyak 18 (18\%) orang, dan yang pernah menggunakan $>3 \mathrm{x}$ sebanyak 82 (82\%) orang.

\section{Pembahasan}

\section{Analisa Regresi Linear Berganda}

Analisis regresi linear berganda digunakan untuk menganalisis pengaruh harga dan kualitas pelayanan terhadap kepuasan pelanggan dengan persamaan regresi linear berganda sebagai berikut :

$\mathrm{Y}=9,391+0,551 \mathrm{X} 1+0,130 \mathrm{X} 2$

Penjelasan persamaan tersebut adalah sebagai berikut:

Konstanta sebesar 9,391 artinya, jika harga dan kualitas pelayanan nilainya 0 , maka kepuasan pelanggan nilainya sebesar 9,391

Koefisien regresi variabel harga sebesar 0,551, artinya jika harga mengalami kenaikan satu satuan, maka kepuasan pelanggan mengalami peningkatan sebesar 0,551 satuan dengan asumsi variabel independen lainnya bernilai tetap.

Koefisien regresi variabel kualitas pelayanan sebesar 0,130 , artinya jika kualitas pelayanan mengalami kenaikan satu satuan, maka kepuasan pelanggan mengalami peningkatan sebesar 0,130 satuan dengan asumsi variabel independen lainnya bernilai tetap.

\section{Uji $t$}

Pengaruh harga (X1) terhadap kepuasan pelanggan $(\mathrm{Y})$ dari tabel diatas terlihat thitung 6,669 dan ttabel 1,984, dimana thitung $<$ ttabel $(6,669>1,984)$ atau tingkat signifikan < alpha $(0,000<$ 0,05). Ini berarti bahwa Harga berpengaruh signifikanterhadap kepuasan pelanggan.

Pengaruh kualitas pelayanan (X2) terhadap kepuasan pelanggan $(\mathrm{Y})$ dari tabel diatas terlihat thitung1,757 dan ttabel 1,984, dimana thitung $<$ ttabel $(1,757<1,984)$ atau tingkat signifikan $>$ alpha $(0,082<0,05)$. Ini berarti bahwa kualitas pelayanan tidak berpengaruhterhadap kepuasan pelanggan.

Harga yang ditetapkan dari pihak kereta api dan kualitas pelayanan yang diberikan berpengaruh terhadap kepuasan pelanggan pengguna jasa kereta commuter linesebesar $30,6 \%$,sehingga dapat dikatakan bahwa harga dan kualitas pelayanan memberikan pengaruh relatif rendah. 
Rendahnya dua pengaruh tersebut dikarenakan adanya ketidaksesuaian antara harga yang ditetapkan atau dicantumkan dengan kesesuaian dalam realisasi harga, dan sisanya sebesar 60,6 $\%$ dipengaruhi oleh variabel bebas lain.

\section{KESIMPULAN \\ Simpulan}

Kesesuaian harga dan kualitas pelayanan berpengaruh positif secara simultan terhadap kepuasan pelanggan.

\section{Saran}

Rekomendasi bagi pembaca karya tulis ini perlu dilakukan penelitian lebih lanjut terhadap variabel selain harga, kualitas pelayanan yang berpengaruh terhadap kepuasan pelanggan pada jasa kereta api. Hal ini dikarenakan, pada penelitian variabel tersebut hanya mampu menjelaskan 30,6\% terhadap kepuasan pelanggan.

\section{DAFTAR PUSTAKA}

Adioetomo, S. M dan O. B. Samosir.2010. Dasar-dasar Demografi. Edisi Kedua. Jakarta: Penerbit Salemba Empat.

Agyapong, Gloria K.Q. 2011. The Effect of Service Quality on Customer Satisfaction in the Utility Industry A Case of Vodafone (Ghana). Canadian Center of Science and Education International Journal of Business and Management, Vol. 6, No. 5; May 2011.

Bintarti, S dan Ergo N. K. 2017. A Study of Revisit Intention: Experiental Quality and Image of Muara Beting Tourism Site in Bekasi District.European Research Studies Journal, Vol. XX, Issue 2A.

Bolton, R.N. and Myers M.B. 2003. PriceBased Global Market Segmentation for Services.Journal of Marketing, Vol. 67, July, pp. 108-28.

Cannon, J.P. AndC. Homburg. 2001. Buyer-Supplier Relationships and Customer Firm Costs.Journal of Marketing, Vol. 65, January, pp. 29-43.
Cronin, J.J. and Taylor S. 1992. Measuring Service Quality: a ReExamination and Extension.Journal of Marketing, Vol. 56 No. 3, pp. 55-68.

Geyskens, I., Steenkamp, J.E.M., and Kumar N. 1999. A Meta-Analysis of Satisfaction in Marketing Channel Relationships.Journal of Marketing Research, Vol. 36,May, pp. 223-38. Geyskens, I., Steenkamp J.E.M., Scheer L.K., and Kumar N. 1996. The Effects of Trust and Interdependence on Relationship Commitment: a Trans-Atlantic Study.International Journal of Research in Marketing, Vol. 13, pp. 303-17.

Kotler dan Amstrong. 2012.PrinsipPrinsip Pemasaran. Edisi Tiga Belas, Jilid Satu. Jakarta: Erlangga.

Moorman, C., Zaltman G., and Deshpande R. 1992. Relationships Between Providers and Users of Market Research: the Dynamics of Trust Within and Between Organizations.Journal of Marketing Research, Vol. 29, August, pp. 31428.

Morgan, R.M. and Hunt, S.D. 1994. The Commitment-Trust Theory of Relationship Marketing.Journal ofMarketing, Vol. 58 No. 3, pp. 2039.

Olifia, Hana dan Sasi Agustin. 2016. Pengaruh Harga, Kualitas Produk,dan Kualitas Pelayanan terhadap Kepuasan Konsumen Kebab Kingabi.Jurnal Ilmu dan Riset Manajemen, Vol. 5, No. 1, Januari 2016. Sekolah Tinggi Ilmu Ekonomi Indonesia Surabaya.

Parasuraman, A., Zeithaml V., and Berry L. 1988. SERVQUAL: AMulti-Item Scale for Measuring Consumer Perceptions of Service Quality.Journal of Retailing, Vol. 64, No. 1, pp. 12-40.

Prasetio, Ari. 2012. Pengaruh Kualitas Pelayanan dan Harga Terhadap Kepuasan Pelanggan.Management Analysis Journal, Vol. 1, No. 4, Agustus 2012. 
Tjiptono, Fandy, 2010.Strategi Pemasaran. Edisi Tiga. Jakarta: Graha Ilmu.

2012.Pemasaran Strategik. Yogyakarta: ANDI.

Wijaya, Chintya Violita. 2017. Pengaruh Harga, Kualitas Pelayanan, dan Kualitas Produk terhadap Kepuasan Konsumen Depot
Madiun Masakan Khas Bu Rudi.Jurnal AGORA, Vol. 5, No. 1. Zakaria, Dianpinsa G. 2017. Pengaruh Kualitas Pelayanan, Kualitas Produk, dan Harga terhadap Kepuasan. Jurnal Ilmu dan Riset Manajemen, Vol. 6, No. 4, April 2017. 